\title{
DISCARDING THE ROSE-COLOURED GLASSES: A COMMENTARY ON ASCH AND MACKLEM
}

\section{THOMAS ISAAC}

The Supreme Court of Canada's 1990 decision of $R$. v. Sparrow' has given rise to much commentary with respect to aboriginal rights and the Constitution Act, 1982. For most aboriginal peoples in Canada, the concept of self-government defines their goals and aspirations best. Although the Sparrow decision does not explicitly discuss the concept of aboriginal self-government, it does constitutionalize existing aboriginal rights in so far as they are "recognized and affirmed" by section $35(1)$ of the Constitution Act, 1982.

Recently, Michael Asch and Patrick Macklem wrote in this journal ${ }^{2}$ an article which questions the underlying assumptions of the Sparrow decision. Although their discussion raises a number of interesting and profound points, it is incomplete and paints a picture of the Sparrow decision that is not entirely accurate.

In their article, Asch and Macklem discuss two theories of aboriginal rights: contingent and inherent. A contingent rights approach depends upon state action for the existence of aboriginal rights whereas the inherent rights approach considers aboriginal rights as being inherent to the definition of "aboriginality" and, therefore, not subject to nor dependent on state action. The authors examine the Sparrow decision in light of the contingent and inherent rights theories. They conclude that, in Sparrow, the court relied upon a contingent theory of aboriginal rights and accepted, unconditionally, Canadian sovereignty. The result is that the court

severely curtailed the possibility that s. $35(1)$ includes an aboriginal right to sovereignty and rendered fragile s. 35(1) 's embrace of a constitutional right to self-government. ${ }^{3}$

The above result in the Sparrow decision, so the authors contend, can be supported only by "a belief in the inherent superiority of European nations" as a result of being based on the "settlement thesis."

The authors propose two alternatives. First, that the settlement thesis be removed as justification for asserting Canadian sovereignty, giving way to the inherent theory of aboriginal rights which would include aboriginal sovereignty and an aboriginal right to

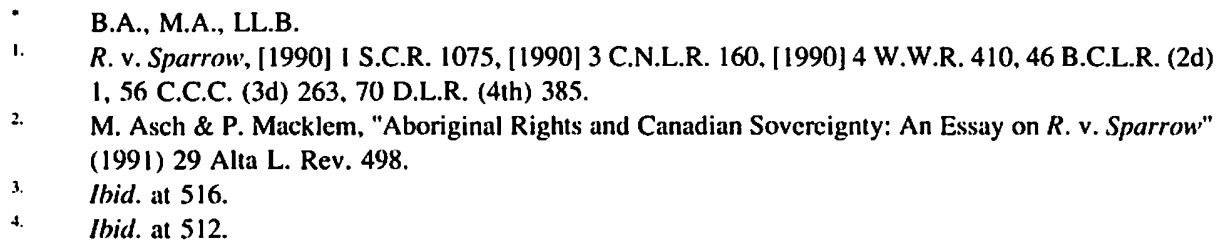

I. R. v. Sparrow, [1990] I S.C.R. 1075, [1990] 3 C.N.L.R. 160. [1990] 4 W.W.R. 410, 46 B.C.L.R. (2d) 1, 56 C.C.C. (3d) 263. 70 D.L.R. (4th) 385.

2. M. Asch \& P. Macklem, "Aboriginal Rights and Canadian Sovereignty: An Essay on R. v. Sparrow" (1991) 29 Alta L. Rev. 498.

Ibid. at 516.

Ibid. at 512 . 
self-government. Second, that section 35 could provide a "fragile foundation for the constitutional recognition of aboriginal forms of self-government."

The authors state that the Supreme Court implicitly relied upon a version of the settlement thesis to justify the assertion that Canada enjoys sovereignty over aboriginal peoples and that, as a result of the settlement thesis, the court supported "a belief in the inherent superiority of European nations." If the court did rely on the settlement thesis, which is not certain, it certainly did not depend on the explicit or implicit recognition of the superiority of European nations. Rather, the court stated a number of times that aboriginal rights must be interpreted in a manner consistent with contemporary society. While the settlement thesis may have originally been rooted in the superiority of European nations, and most likely was, the Supreme Court has adopted $a$ thesis, not necessarily the settlement thesis, which supports Canadian sovereignty as a matter of political and legal reality and not one which necessarily relegates aboriginal peoples to a substandard social status. The authors note ${ }^{7}$ that one of the various recognized ways of asserting sovereignty is the method of annexation or assertion of sovereignty. The Supreme Court may have combined a modern interpretation or form of the settlement thesis with the annexation approach to assert Canadian sovereignty.

The premise underlying this discussion is that the Supreme Court is dealing with the laws of Canada and therefore must look to the Constitution of Canada as being supreme law as per section 52 of the Constitution Act, 1982. Because Canada is a sovereign state, no other law or assertion can override the authority of the Constitution. To assume that the assertion of Canadian sovereignty is rooted in a belief in the superiority of European nations is presumptuous in light of the fact that the court goes out of its way to state its respect for aboriginal rights and culture. Although the settlement thesis might have been questioned strongly 120 years ago on the basis that it reflected the superiority of European nations, such is not the case today. While incidents of racism have appeared and continue to appear against aboriginal peoples in Canada, there is no evidence to suggest that the court relied on a theory that is based on racism.

The court has accepted Canadian sovereignty as a legal and political reality. It does so not on the basis that European nations are superior, but rather that Canadian sovereignty is a well-established fact in the political and legal framework of Canada. Aboriginal sovereignty, if not explicitly, then implicitly, has been extinguished for centuries. Any recognition of aboriginal sovereignty must take place within the existing legal and constitutional framework. Once this is recognized, aboriginal sovereignty becomes the wrong term to use because sovereignty denotes a form of absolute power. Both inherent rights theory and aboriginal sovereignty are based upon notions of absolute power. Inherent aboriginal rights are not dependent upon the state and are, therefore, absolute. The use of this type of language is not productive. It aims for the unattainable

\footnotetext{
Ibid. at 515.

Ibid. at 512 .

Ibid. at 511 .
}

Études constitutionnelles 
not only at law but also politically. Absolute power, as found in inherent rights and "sovereignty," is unfounded for aboriginal peoples. This is not to suggest that forms of a right of aboriginal self-government should not be recognized. Indeed, aboriginal selfgovernment is a worthy goal, but only within the confines of Canadian sovereignty. That said, the language of inherent rights, strictly defined, and aboriginal sovereignty must be discarded.

Although this author disagrees with Chief Justice McEachern's analysis of aboriginal rights in the British Columbia Supreme Court decision of Delgamuukw v. B.C., ${ }^{8}$ his discussion of aboriginal sovereignty is noteworthy. He writes:

\begin{abstract}
No court has authority to make grants of constitutional jurisdiction in the face of such clear and comprehensive statutory and constitutional provisions. The very fact that the plaintiffs recognize the underlying title of the Crown precludes them from denying the sovereignty that created such title. ...neither this nor any court has the jurisdiction to undo the establishment of the colony, Confederation. or the constitutional arrangements which are now in place. Separate sovereignty or legislative authority, as a malter of law, is beyond the authority of any court to award. ...Canadian ...sovereignty is a legal reality recognized both by the law of nations and by this court."
\end{abstract}

The authors propose that, in the alternative, the Sparrow decision can be interpreted to support a recognition of aboriginal self-government. This may be true, but only contingent self-government could be recognized. Inherent self-government, or aboriginal sovereignty, is absolute and therefore cannot be said to exist. Throughout Sparrow, Canadian sovereignty is asserted whereas aboriginal sovereignty is not mentioned. The court writes that

there was from the outset never any doubt sovereignty and legislative power, and indeed the underlying title, to such lands vested in the Crown. ${ }^{10}$

It is important to note that while sovereign power should not be doubted, it is not absolute with respect to $s$. 35 . This opens the door for a contingent right of self-government to be recognized and still have legislative clout. The court states:

we find that the words recognition and affirmation incorporate the fiduciary relationship referred to earlier and so import some restraint on the exercise of sovereign power."

Probably one of the most telling aspects of the decision with respect to self-government is where the court states that its interpretation of $\mathrm{s.} 35$ "provides a solid constitutional base upon which subsequent negotiations can take place." ${ }^{2}$ "Subsequent negotiations"

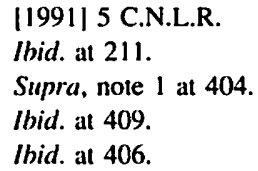


probably refers to negotiations with respect to land claims agreements and future constitutional talks with respect to incorporating explicitly a right of aboriginal selfgovernment into the Constitution. To some extent, the words of the court have been fruitful with the federal government proposals to constitutionalize some form of selfgovernment. The court does not rule out the possibility that an existing right of selfgovernment may already exist in s. 35 (that is, a contingent right). However, the court does exclude the possibility that s. 35 holds an inherent or absolute right of selfgovernment by stating that s. 35 "does not promise immunity from government regulation."13

The authors state that fishing was considered to be a right by the court "because of its centrality to Musqueam culture. ${ }^{14}$ As a result, the ability to determine how the right shall be implemented must also be central to the culture and, as such, must also be considered an aboriginal right under s. 35 . This reasoning is sound. However, not only was the right to fish considered a s. 35 right because of its centrality, but also because it was not extinguished. If it had been extinguished prior to April 1982, then the discussion of centrality would have been irrelevant. The right to fish is not absolute. It is still subject, to some extent, to the federal regulatory scheme. The court makes this clear. However, even if this were not the case, and it were determined that aboriginal peoples could decide how to exercise their right to fish, this right could not be akin to sovereignty. The power to regulate, by itself, does not equate to sovereignty. Rather, at most, it may equate to a limited form of self-government which is already in place in various forms across Canada. This is not to suggest that regulation-making powers are not important. They can be significant but they do not represent sovereignty.

Nowhere is an aboriginal right of self-government, in the inherent or aboriginal sovereignty form, recognized. Many cite the Royal Proclamation of $1763^{15}$ as evidence of aboriginal self-government being recognized. Yet, regardless of the claims of many, nowhere in the Proclamation is such power to be found. While the Proclamation is a solid base for arguing the existence of a number of "inherent" rights (i.e. fishing and hunting), no such basis exists in the case of self-government, at least inherent selfgovernment.

The court stresses the importance of defining aboriginal rights in modern language that takes into consideration relevant political, social, and legal consequences. The court writes that the constitutional recognition afforded to aboriginal rights in $\mathbf{s .} 35$ is given

in a society that, in the twentieth century, is increasingly more complex, interdependent and sophisticated. and where exhaustible resources need protection and management... ${ }^{16}$

13. Ihid. at 410 .

14. Supra, note 3 at 506.

1s. R.S.C. 1985, app. Il, no. 1.

16. Supra, note 1 at 410 . 
The authors present some interesting and profound insights into the Sparrow decision for which they are to be congratulated. However, while their article raises some noteworthy points, it lacks a sense of the political and legal reality of Canada. Paramount to this reality is Canadian sovereignty. Absolute sovereignty in the forms of an inherent aboriginal right of self-government or aboriginal sovereignty is politically unfeasible and legally unsupported.

The authors note that their interpretation may not be "palatable to a legal imagination that views the world through a particular set of evolutionary lenses." ${ }^{17}$ This is true. The "rose-coloured" interpretation is not palatable to this writer. Their views are interesting but do not appear to consider the legal reality of Canadian sovereignty and the difficulty of absolute terminology such as "inherent" and "aboriginal sovereignty." Inherent selfgovernment must be based on "something" and until that "something" is produced in concrete form, the evidence suggests that no such right exists. One's imagination must be tempered by realism.

What has been written is not meant to suggest that this writer is against an interpretation of section 35 that may include a right of self-government. Indeed, such a right is welcomed, but only a right that is realistic. In order for realism to prevail, absolutism must be forgotten. The language of absolutism in this debate on selfgovernment is misleading. It is the unattainable and unthinkable. Of course, in order for a right of self-government to work, outside of absolute sovereignty, the federal and provincial governments must support such a right with solid funding and infrastructural support. Until that is constitutionally guaranteed, aboriginal peoples have every right to be wary of future promises. 